\title{
Chapter 8: Russia's Agri-Food Trade Within the Eurasian Economic Union
}

\author{
Rilka Dragneva
}

\section{INTRODUCTION}

The pursuit of economic integration has been a key dimension of Russia's policies in the post-Soviet region. After several failed initiatives, the first real achievement was the creation of a Customs Union (CU) with Belarus and Kazakhstan in 2010. It was followed by the launch of a Single Economic Space (SES) in 2012, ultimately culminating in the formation of the Eurasian Economic Union (EAEU) in 2015, to which Armenia and Kyrgyzstan also acceded. ${ }^{1}$ As its predecessor, the EAEU aims at 'deep' economic integration: one where not only mutual trade in goods is liberalised, but the formation of a common market is pursued through the harmonisation of domestic regulatory requirements and other nontariff barriers. In the external plane, the objective has been to exercise a common policy through the adoption of a Union external tariff, a common trade protection regime and the engagement in trade agreements with the rest of the world as a unified trading bloc. To achieve these goals, the EAEU member states have endowed the organisation

\footnotetext{
R. Dragneva $(\otimes)$

University of Birmingham, Birmingham, UK

e-mail: R.DragnevaLewers@bham.ac.uk
}

(C) The Author(s) 2022

S. K. Wegren and F. Nilssen (eds.), Russia's Role in the Contemporary

International Agri-Food Trade System, Palgrave Advances

in Bioeconomy: Economics and Policies,

https://doi.org/10.1007/978-3-030-77451-6_9 
with a system of bodies with delegated powers and an international legal personality.

Such an ambitious project is bound to affect the economies of its member states, including the production and trade of food, in tangible and fundamental ways. Therefore, the understanding of Russia's role in the international food trade system will be incomplete without taking into account the agency of the EAEU and the opportunities created by it. Yet, while undoubtedly significant, this relationship is not straightforward. Firstly, despite some notable achievements, developments on the ground have been modest or outright disappointing. In mutual trade, in particular, the results have been described as erratic, with significant variations across sectors and member states. ${ }^{2}$ Notably, relations have been interlaced with high-profile trade conflicts and back-tracking from previous achievements. Secondly, while some of these dynamics can be explained by external conditions or natural 'growth pains', it is largely symptomatic of the structural problems of the EAEU as an integration project: its highly politicised and decentralised nature, the limitations of its legal regime and the weakness of its common bodies. ${ }^{3}$ This has allowed Russia to use its power preponderance in the region to assert its policy priorities and especially its geopolitical considerations through the EAEU, where possible, but also despite the EAEU, where necessary.

This chapter will unpack this dynamic by analysing the role of the $\mathrm{CU}$ and EAEU in Russia's agricultural food trade. In particular, the aim will be to discuss: (1) To what extent has the formation of the EAEU impacted on Russia's food trade with its neighbours, both in terms of the institutional regime set up and the resulting ability of the organisation to affect its members' trade practices? (2) In what ways has the EAEU affected Russia's options as a player in the international food system? Given that the birth of the EAEU coincided with a major reversal in Russia's trading behaviour as a result of the sanctions' war with the West, ${ }^{4}$ what role has the bloc performed in this process?

The chapter will begin by providing a background of the key relevant institutional features of the EAEU. It will then focus on some of the most important yet also problematic ways in which the EAEU affects agri-food trade and production, namely the EAEU's food safety regime, the effects of Russia's food import ban, the agenda for agricultural cooperation, including the coordination of food security policy, and the opportunities provided by concluding EAEU free trade agreements with third parties. In conclusion, the chapter will examine some of the changes in agri-food 
trade flows since the launch of the EAEU, before offering some thoughts on the outlook for the future.

\section{The EAEU and Its Institutions}

To understand the role of the EAEU in affecting Russia's role in regional and international agri-food trade, it is necessary to point out some of its general characteristics as an institutional regime. The EAEU was set up as an independent interstate actor operating through its bodies on the basis of the powers delegated by its member states. Of particular significance is the Eurasian Economic Commission (EEC), the Union's regulator tasked with the development of integration. The Commission is a two-tiered body consisting of a Council that is composed of the deputy heads of national governments, and a Collegium that is composed of Ministers nominated by the member states who head specialized departments. ${ }^{5}$ Despite the intention to model it on the European Union Commission, however, the EEC's autonomy and authority are highly limited.

The EEC has been endowed with significant powers in the area of tariff and customs regulation, technical regulation and the imposition of trade defence measures. Many other areas, such as transport or agricultural policy, are reserved for the member states. In relation to those, the Commission's role is to facilitate cooperation between the member states. Even within the area of delegated powers, however, there is complex mix between Union and national legislation and between Commission and national competences to navigate, as the area of food safety illustrates.

Furthermore, the decision-making process that the EEC follows even in such areas is deeply intergovernmental, putting member states firmly in control. The most important powers of the EEC are exercised by its Council by consensus. The Collegium is the permanent and most professional and independent body of the Union, consisting of departments dealing with day-to-day matters. Its decisions, however, can always be challenged by member states and escalated to the Council of the Commission or the higher bodies of the EAEU, the Inter-Governmental Council (heads of government), and the Supreme Eurasian Economic Council (heads of state), and revoked or reversed by them.

Notably, the powers of the Commission are particularly curtailed by its weak enforcement functions. It can, subject to capacity, monitor member states' practices and notify them of a lack of implementation or breach of Union requirements. Yet, in a reversal from the CU regime, it cannot 
bring them before the Court of the EAEU. It is notable that the EAEU Treaty asserted the primacy of the member states in several key ways, including by restricting the Court's powers and ensuring that its rulings do not become part of EAEU law. ${ }^{6}$

In this context, the Commission has acted cautiously and conservatively. Even when it demonstrates activism, the fate of its initiatives rests at the highest level of domestic power. Thus, politicised interstate bargaining is the main path to secure progress or resolve disagreements. This characteristic matters for a number of reasons.

Firstly, there is a mismatch between the institutional regime in place and the stated ambition of integration. There is an 'attainment gap' built into the system which is particularly critical in relation to the removal of non-tariff barriers and regulatory alignment. In part, this is connected to the preference for harmonisation similar to the European Union (EU), which is an inherently complex process. ${ }^{7}$

Secondly, it can be argued that the institutional set-up behind the mismatch was the result of the member states' deliberate preference. As the drafting of the EAEU Treaty coincided with the eruption of the Ukraine crisis in early 2014, Russia's partners were keen to limit the scope of integration and, particularly restrict the power of common bodies. With sovereignty sensitivities ignited, Belarus and Kazakhstan were concerned about Russia's ability to dominate the Union and develop a political dimension to economic integration. ${ }^{8}$

Finally, the functioning of the EAEU as well as any improvements of the regime depend on the engagement and continued commitment to the integration of its member states. This is particularly crucial given the large number of areas of cooperation, including the completion of the common market, which are 'in progress' and depend on future actions being taken. Indeed, despite the fact that it inherits developments set in motion with the 2010 Customs Union and 2012 Single Economic Space, the EAEU is best understood as a 'road map' for cooperation.

This links to another important point. In law, the EAEU operates on the basis of formal parity between its members reflected in their voting power and composition of common bodies. Nonetheless, Russia's leadership in the operation of the Union is hard to dispute. It is evident in the staffing of the Collegium of the EEC and Russia's superior ability to lead and participate in various working groups and joint missions, particularly in the area of food safety. ${ }^{9}$ It is also a result of its massive 
structural preponderance within the economy of the EAEU, which translates into a high degree of identification of the EAEU interest with Russia's interest. ${ }^{10}$ Ultimately, it represents the political reality behind the EAEU, which is largely based on bilateral, Russia-centred hub-and-spoke patterns of interactions, where the loyalty of members is procured by the provision of collateral benefits, including political support, cheap energy, or enhanced security. ${ }^{11}$

In this sense, it is of particular importance that Russia's key interest in the Eurasian project is primarily (geo-) political. The economic benefits of EAEU integration for Russia, even with the removal of non-tariff barriers, have been estimated as trivial. ${ }^{12}$ Russia certainly derives little economic advantage from the bloc above and beyond what it can achieve through bilateral dealings. It is not surprising that Russia has been prepared to let geopolitics trump the constraints of integration at the expense of the Union, but also that its interest in the technical minutiae of integration has not paralleled its enthusiasm for more symbolic wins, such as the launch and expansion of the bloc. It has certainly been selective in driving integration, investing primarily in areas where geopolitical considerations or other domestic priorities have been most prominent.

All this is aptly demonstrated by the case of agri-food trade. In terms of mutual trade in goods, the EAEU inherited the tariff-free trade arrangements already put in place between its members in a web of bilateral free trade agreements and related agreements facilitating trade cooperation. These arrangements were critical in eliminating the various annual exemptions to free trade, which created high uncertainty in bilateral dealings. They did not, however, tackle non-tariff barriers and particularly, the possibility to apply Sanitary and Phyto-Sanitary Measures (SPS) as barriers to trade. Despite Belarus's close alliance with Russia, for example, it periodically experienced food bans and customs restrictions, largely perceived as discriminatory and politically motivated. ${ }^{13}$ The launch of the Customs Union in 2010 consolidated the free trade arrangements already in place, brought about a common Customs Code and the highly symbolic removal of internal customs controls in 2011. It also created a new momentum for deeper integration, including the adoption of common technical requirements and other coordination measures. The EAEU inherited these developments with the idea to embed them in a more coherent legal and institutional framework and map out an ambitious agenda for achieving a genuine common market. Nonetheless, agri-food trade under the EAEU regime remains inhibited by several 
important obstacles linked to the nature of its institutional regime and its limited ability to constrain the diverging preferences of its members, Russia, in particular.

\section{Food SAFety Requirements}

While food safety is fundamental to the functioning of the common market, it is one of the areas where the obstacles to internal trade are most pronounced with disputes between the EAEU members continuing to proliferate. This is largely attributed to the fact that, as aptly described, the EAEU regime does not amount to a workable single food safety system but rather a conglomeration of the national systems of its member states. $^{14}$

To start with, it should be pointed out that at the level of the WTO and the practice of various countries, the regulation of technical barriers to trade and the use of SPS measures are clearly distinguished and defined. Russia, however, has followed an approach where in regulating food safety, the boundaries between the two have been blurred. ${ }^{15}$ This approach influenced the practice of the Customs Union, ${ }^{16}$ and was then inherited by the EAEU. Thus, food safety in the EAEU straddles issues related to the adoption of Union 'technical regulations', which have included sanitary requirements and procedures with regard to an agreed list of commodities as well as the framework for SPS control.

In this sense, the area of food safety presents some complications in the applicable regimes, particularly in relation to products of animal origin. ${ }^{17}$ With regard to technical requirements, the EAEU pursues maximum harmonisation. In law, regulations need to be applied directly in the member states, without the need of implementing legislation, thus aiming to reduce the possibility for divergence. In the area of SPS, however, member states are allowed to impose additional requirements and put in place additional processes for assessing conformity. ${ }^{18}$ Indeed, in terms of SPS controls, the EAEU operates an agreed (soglasovannuiu) policy, ${ }^{19}$ a term which was deliberately used in drafting the Treaty to designate the lowest level of interstate cooperation.

In principle, the EAEU Treaty lays down the fundamentals of food safety policies in line with WTO requirements, dealing with the purposes of food safety measures, scientific risk assessment, regionalisation of food safety risk, transparency and the importance of international standards. ${ }^{20}$ The EAEU system is based on the provision of common mandatory 
requirements and general procedures applying to an agreed list of goods placed under regulatory control. General sanitary requirements and procedures for sanitary control were agreed upon by the CU Commission in $2010 .^{21}$ They were developed in a number of horizontal technical regulations, such as the 2011 Technical Regulations 'On Food Safety', 'On the safety of packaging', and 'On food products in relation to labelling'. More detailed mandatory requirements to the products subject to sanitary controls were envisaged in specific technical regulations dealing with certain types of food products, such as meat, milk, grains, fat and oil products, and fruits. ${ }^{22}$ These were accompanied by the provision of common rules on conformity assessment, standard forms of documents of compliance, and a register of certification bodies. Similarly, in the area of veterinary controls, there were adopted common requirements applicable to the commodities subject to veterinary control and agreed veterinary control procedure to be applied at the EAEU customs border and throughout its customs territory. ${ }^{23}$ This also involved the adoption of uniform veterinary certificates, as well as general rules applying to different aspects of the veterinary control process, such as laboratory controls and joint inspections.

These mandatory requirements and procedures have been developed and continue to be updated at the EAEU level by the EEC, as they were by its predecessor, the Commission of the CU. Nonetheless, the progress in adopting and upgrading technical regulations has been slow and complicated: in the Commission's own assessment, this is an area plagued by the delays and perfunctory attitudes of EAEU member states. ${ }^{24}$

Related to this is the problem of the control over the compliance with technical regulations. This is an area where discrepancies and inconsistencies are common. In a recent example, Russia adopted requirements regarding the marking and marketing of wine, in addition to the EAEU technical regulation 'On the safety of alcohol production', due to enter into force in $2021 .^{25}$ However, the EEC has no powers in this regard: control is a prerogative of national authorities in accordance with national systems of food control. ${ }^{26}$ Inspection, enforcement, or indeed the pursuit of liability in the case of breaches takes place subject to domestic legislation and procedures, and is open to significant divergence. The EAEU Treaty provides that a future international agreement may harmonise domestic legislations dealing with control over compliance. ${ }^{27}$ This, however, has not materialised, nor is there an indication that such a harmonisation will result in more powers of the Commission. Instead, 
the Commission has sought to respond to problems in this field by issuing recommendations for improved cooperation between member states. ${ }^{28}$

Similarly, the exercise of sanitary and veterinary control is carried out by domestic authorities applying Union as well as national rules. The Commission does not participate in joint inspections nor has the authority to audit the national systems of control. ${ }^{29}$ Even more importantly, in contrast to the EU regime, ${ }^{30}$ the Commission does not have the right to adopt temporary SPS measures under any circumstances.

The imposition of temporary SPS measures is the exclusive right of the member states. It can be triggered by notification by another member state of problems or measures adopted on its territory, but also by the imposing state's own finding of a violation of technical regulations or a 'deterioration of the sanitary-epidemiological situation on the territory of member state'. ${ }^{31}$ This allows for a wide discretion in the imposition of temporary SPS measures, subject only to the requirement to follow a process for mutual notification and consultation, introduced in May 2016. ${ }^{32}$ This is especially problematic given the important gaps in the common SPS regime in key areas, such as the definition of deterioration or threat, or how a risk analysis should be conducted. ${ }^{33}$ Indeed, in the Commission's own assessment, 'Union law does not define the key terms related to temporary SPS measures, the justification for their introduction and contents, which can give rise to inappropriate use of such measures'. 34

All this gives rise to two important problems. Firstly, food safety ultimately depends on the capacity and effectiveness of the domestic systems for inspection and enforcement. This underscores the importance of the quality of domestic institutions and the need for their modernisation. However, this conclusion jars against the fact that the EAEU project explicitly lacks a 'governance' dimension. Accession to the EAEU, for example, does not depend on preparedness to implement the various EAEU requirements, nor is support for developing domestic capacity a part of any EAEU equivalent of the EU structural and regional funds. The rudimentary state of SPS control facilities of Kyrgyzstan, for example, was well known to members of the EEC, ${ }^{35}$ yet Russia's geopolitical priorities prevailed in pressing for its fast accession. It is telling that Kazakhstan refused to remove its phytosanitary posts from the border with Kyrgyzstan until October 2016, following pressure at the EAEU level. 
A closely related problem is that of the corrupt practices of the various national agencies for inspection and certification. Indeed, there have been abundant demonstrations that a domestic 'market for documents' has developed in several countries, ${ }^{36}$ undermining the integrity of the system. This is particularly problematic in areas, such as the issuance of veterinary certificates, which are subject to mutual recognition across the Union. ${ }^{37}$

Secondly, this decentralised nature of the SPS regime opens the possibility for arbitrary or opportunistic use of restrictions. The EAEU Treaty provides that SPS measures and import bans should not represent unjustifiable discrimination of a disguised restriction on trade and should only serve a list of agreed purposes. ${ }^{38}$ Yet, Russian SPS measures continue to be perceived by Belarus as driven by protectionist or political motivations. Russia's 2018 ban on dried milk, for example, was interpreted as an attempt to curtail the entry of the cheaper, subsidised Belarussian products. ${ }^{39}$

Both these problems culminated in the context of Russia's food embargo, as will be examined next.

\section{Russia's FOOD IMPORT BAN AND Its EFFECTS ON EAEU RELATIONS}

It is not an exaggeration to say that at the same time as the EAEU was being launched as an integration-enhancing project, it was crippled by the consequences of Russia's decision to ban food imports from the EU, the U.S. and a range of other countries, initially imposed in August 2014 and extended to the end of 2022. ${ }^{40}$ Given the refusal of Belarus and Kazakhstan to agree on a Union-wide ban, this unilateral action meant that the very logic of functioning as a customs union based on a common external trade policy was undermined. ${ }^{41}$ Similarly, complications arose following an import ban on Ukrainian agri-food products in 2016 and also extended to the end of 2022. There were also transit restrictions through Ukraine so that Kazakh and Kyrgyz importers faced higher transaction costs, leading to the actual economic detriment.

In the absence of an EAEU-wide framework, Russia's options to enforce its import ban have been limited. To start with, Belarussian President Lukashenko pledged to cooperate in securing the control of the EAEU external borders. ${ }^{42}$ This was also an opportunity to increase Belarus's food exports to Russia as well as help alleviate Russian consumer losses from the collapse in imports. Yet, as widely discussed, the reality was 
a boom in 'contraband' trade in dairy, fruit, fish products, and others, using a variety of schemes, such as relabelling, falsifying certificates of origin, and violating transit rules. While the case of Belarus has been publicised most, the other partners did not shy from seeking to profit from the sanctions regime either.

With its initial offers to set up joint missions at the Union customs borders and engage in other forms of customs cooperation rejected, Russia resorted to introducing customs and food safety checks in areas bordering on Belarus and Kazakhstan. In effect, this not only caused traffic delays but rolled back the integration achievements already made, resulting in the emergence of a de facto two-tier customs regime. ${ }^{43}$ Furthermore, Moscow sought to defend its market as well as place pressure on Belarus to abandon its policy of profiting from the sanctions through the extensive use of temporary SPS measures. For example, while pointing out the presence of antibiotics in violation of EAEU food safety requirements, Rosselkhoznadzor also referred to a systemic, organised falsification of milk products and the certificates accompanying them. ${ }^{44}$ This pushed the agency to move from enterprise bans to a sectoral ban on the import of some milk products in the spring of 2018, which was eventually retracted.

Given the decentralised nature of the SPS system, throughout this period, the main form of seeking progress in resolving the recurrent disputes was through bilateral dealings, with joint working groups being set up and annual road maps adopted. At the same time, both sides also sought to use the EAEU platform, which exposed the deficiency of the common institutions even further. Belarus was successful in mobilising its Commissioners to lobby for its case, arguing that 'violations unconnected to veterinary risks should not be the basis for the imposition of restrictive veterinary measures'. ${ }^{45}$ Following the 2018 'milk war', the EEC Collegium sided with Belarus adopting several decisions calling on Russia to remove various measures representing obstacles to the functioning of the internal market contrary to the requirements of the EAEU Treaty. ${ }^{46}$ In particular, the Commission took the view that there is no EAEU legal mechanism for a country to refuse to recognise a veterinary certificate adopted by other country's authorities. ${ }^{47}$ Given the limited powers of the Commission, however, the effect of its notifications to Russia remained largely symbolic, with disputes entering the province of highest level of political bargaining. 
At the same time, Russia sought to address the problem of contraband goods or 'grey' trade (seryi oborot) at the EAEU level by leading on key developments. For example, in February 2018, an agreement on product marking was successfully signed by the EAEU member states. It aims at unifying the different countries' approaches to the product marking and, thus, improving the traceability of certain products. In May 2019, an Agreement on the traceability of products imported into the EAEU customs territory was also signed. It is expected to help reduce the circulation of illegal goods and increase business transparency. It is also unsurprising that Russia has seen the development of the digital agenda in the EAEU as one of its top priorities over other areas in need of attention. Yet, as Kofner points out, there remain a range of technical difficulties in harmonising domestic digital tracing systems, not least because of the prominence of private business interests involved in their operations. ${ }^{48}$

\section{Cooperation in the Food Security Agenda}

As extensively discussed elsewhere, over the last decade, Russia's food policy has been defined by its food security agenda. ${ }^{49}$ Russia's Food Security Doctrine, adopted in 2010, pursued self-sufficiency through assistance for domestic agricultural production in addition to restrictions on specific imports. This was given a new impetus by the food embargo of August 2014, which was followed by Moscow's launch of an extensive import substitution policy in October 2014. Against this background, food security acquired a distinct political and security importance, affecting Russia's preferences vis-à-vis developments in the EAEU.

This is an area where Russia's leadership has been in full display. This was possible also because food security was already an important issue in the region. For example, Armenia adopted a food security law in 2002; Belarus adopted its own Food Security Concept in 2004; Kazakhstan included food independence in its 2005 Law on state regulation of the development of the agricultural complex and rural territories; and Kyrgyzstan passed a law on food security in 2008. These acts were followed by various programmes, concepts, and strategies detailing and updating the food security agenda. While the definitions of food security, the targets set for self-sufficiency of the domestic production of different commodities and the domestic support measures to achieve them varied widely, ${ }^{50}$ the general concern was shared as was its association with the wider issue of national security. Furthermore, Food 
Security Concepts were adopted at the regional level of some of the preceding integration projects, namely the Eurasian Economic Community in 2009 and the Commonwealth of Independent States in 2010, which to a large extent reflected the Russian concept and food security targets. Recently, a EAEU-wide Concept was drafted and distributed for consultation. As a result, the EEC has monitored the levels of domestic self-sufficiency, producing 'league tables' of the progress of the different countries towards this goal.

Against this background, the EAEU Treaty provided somewhat broadly for the achievement of a coordinated agricultural policy 'to optimise the volumes of production', 'satisfy the needs of the common agricultural market', and 'increase the export of agricultural products and food'. 51 This was a distinctly decentralised policy, carried out by 'regular consultations of the representatives of the member states, organised by the Commission' and followed by the adoption of recommendations. ${ }^{52}$ The centrepiece of this coordination was the mutual sharing of the programmes to support the production of an agreed list of sensitive agri-foods. This list adopted in 2016 included milk and milk products, meat and meat products, vegetables, fruits, rice, seeds, sugar, cotton, and tobacco. ${ }^{53}$ Furthermore, the Treaty in its Annex 29 attempted to formulate some common principles for the adoption of state support depending on their effect on mutual trade, requiring member states to abstain from the adoption of certain measures. Nonetheless, as in other cases, any disputes with regard to this area of cooperation are to be resolved by interstate consultations, with the Commission performing a purely facilitating function.

The Commission has argued that national import substitution programmes should be developed with a consideration of EAEU imports so as to help the specialisation and competitive advantage of the different member states. ${ }^{54}$ In this area, Russia has shown some interest in expanding the import substitution agenda to the level of the EAEU. In July 2020, a EAEU Road-Map on the development of agricultural industry was adopted, which moves forward cooperation in this field. ${ }^{55}$ However, Russia was reluctant to open its public procurement market to EAEU companies, which attracted many complaints, especially by Belarus, alleging distortion of the common market. In 2018 Russia finally admitted EAEU companies to its import substitution programme. Nevertheless, as commentators point out, there remain numerous substantial obstacles to EAEU companies taking part in Russian tenders. ${ }^{56}$ 


\section{EAEU's External Agreements}

One area where the EAEU boasts a potential to make a difference to its members' external trade is in fostering relations with third parties. Indeed, the EAEU has been active in signing various cooperation memoranda and negotiating trade deals across the globe. To date, the EAEU has successfully signed free trade agreements with Vietnam (2015), Iran (2018), Singapore (2019), and Serbia (2019). Certainly, one might expect that such agreements might contribute to Russia's geographical reorientation of post-sanction imports as well as crate new export opportunities. Yet, the benefits of these agreements so far can be described as marginal.

The agreement with Vietnam is a case in point (see also Chapter 7). It provides for the liberalisation of 88 percent of trade in goods, with 59 percent of tariff eliminated upon entry into force and 29 percent removed over a five to ten-year period. ${ }^{57}$ In terms of export opportunities, the agreement hailed the possibility of reaching a market of 90 million people. It secures the immediate removal of tariffs on key commodities, such as wheat and linseed. It also creates opportunities for growing markets in products, such as milk, poultry, and confectionaries, subject to transition periods. In terms of imports, the agreement liberalises the access of goods, such as fish, rice, and fruit. Yet, it excludes competing 'sensitive' commodities, such as meat, milk, tea, coffee, and sugar, thus protecting domestic producers. Furthermore, the EAEU reserves the asymmetric right to apply trigger safeguard measures to control the volume of some imports, such as rice. It similarly relies on quotas and the application of non-tariff barriers, including SPS measures. ${ }^{58}$ Protectionist measures were particularly relevant to the case of Belarus, which stood to lose most from free trade with Vietnam. ${ }^{59}$

Five years on, not all EAEU members have benefitted from the agreement. ${ }^{60}$ Trade data shows that Russia's total imports from Vietnam have grown, while its exports have been more erratic. ${ }^{61}$ Yet, ultimately, the economic significance of this agreement is limited given Vietnam's share in the EAEU members' external trade. Even for Russia, which accounts for the highest volume of EAEU trade with Vietnam, this share is less than 1 percent. ${ }^{62}$

The picture is similar in terms of the temporary FTA with Iran, accounting for 0.28 percent of Russia's external trade in 2018. During the first eight months of 2020, total trade between the EAEU and Iran totalled about \$2 billion USD, of which, food and agricultural goods 
amounted to $\$ 939$ million USD. ${ }^{63}$ Furthermore, the temporary agreement with Iran is limited in its scope and commitments on both sides. ${ }^{64}$ It applies to a short list of commodities, representing about 50 percent of existing trade. The EAEU liberalises tariffs on mostly non-sensitive goods, whereas trade in some competing goods, such as vegetables, is restricted to seasonal preferences. In November 2020, however, it was reported that the EAEU and Iran would sign a permanent free trade agreement, which presumably would increase trade and remove current restrictions. ${ }^{65}$

This trend is even more pronounced with regard to the recently signed FTAs with Singapore and Serbia. As Singapore already operates a dutyfree access, in the words of the Commission, an FTA 'is not of interest to the CU members by virtue of its foreign trade effects'. ${ }^{66}$ Similarly, the agreement with Serbia consolidates existing agreements and offers few new advantages to bilateral trade with Moscow.

The EAEU has also been negotiating agreements with Israel since 2015 and with Egypt and India since 2016. In terms of the attraction of Israel, like with Singapore, its key benefits lie outside trade in goods. While Russia is likely to benefit from grain exports and fruit and vegetable imports from an agreement with Egypt, negotiations have been slow. Reaching an agreement with India is even more problematic. EAEU assessments show significant negative effects of deepened engagement with India particularly for Belarus, short of exemptions relating to dairy and meat products. ${ }^{67}$ At the same time, given India's protectionist record, the extent of market access concessions to obtain should not be overestimated.

While some opportunities are created by these agreements, they are not concluded with major trade partners and the primary reason for pursuing them has not been economic. Above all, they align with Russia's particular geopolitical objectives in the respective regions, while promoting an agenda to establish the EAEU as an internationally recognised player. ${ }^{68}$ They are more about Russia's regional clout and the economic alignment with important geopolitical shifts rather than about trade liberalisation. Improved market access has been more part of their justification rather than their impetus. Ironically, the very fact that they cover small volumes of trade has helped make them possible in achieving the consensus for signing them in the face of domestic protectionist pressures. ${ }^{69}$

In this sense, it is notable that the bulk of the growth in Russia's external markets since 2014 has been outside the framework of EAEU's free trade agreements. At the same time, while the prominence of trade 
with China has grown and cooperation opportunities at the level of the EAEU have been explored, the possibility for a free trade agreement is not on the table. Instead, in 2018 the EAEU signed a non-preferential agreement designed to serve as the basis for future economic relations. Yet, in terms of its contents, this is primarily a politically symbolic agreement, with little added value to cooperation other than restating existing WTO commitments.

\section{How Trade Flows Have Changed}

Against this background, it is not surprising that the picture of agri-food trade in the EAEU presents mixed results. To start with, the EAEU inherited a rising trend in mutual agri-food trade between Russia, Belarus, and Kazakhstan despite declines in total trade in 2012. ${ }^{70}$ The launch of the EAEU was marked by a sharp currency depreciation against the U.S. dollar, and the entry into force of Russia's import food ban, which led to a reduction in Russia's total agri-food imports in 2014 and 2015.71 This trend was also reflected in trade with Russia's EAEU partners (see Fig. 1), even though as the EEC notes, the fall in agri-food trade was not as pronounced as the fall in other commodity groups. ${ }^{72}$

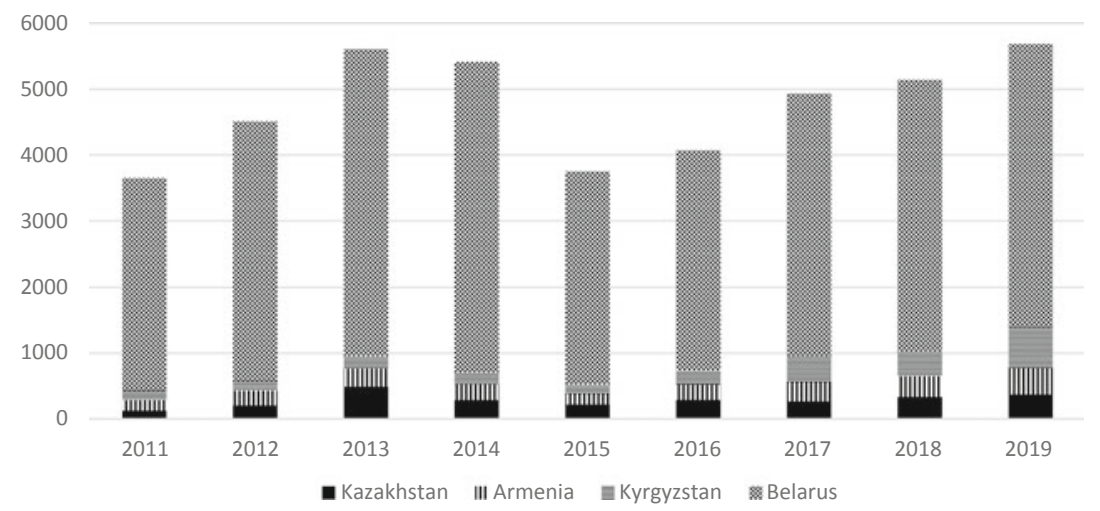

Fig. I Value of Russia's agri-food imports from the EAEU (million USD) (Source Author's calculations based on EEC's Statistics on trade in agri-food products) 
Since 2015, there has been a gradual yet important increase in Russia's agri-food imports from the EAEU, indicating that geographical reorientation as a result of the sanctions war has taken place. This increase has been fairly unequal across EAEU partners: imports from Armenia and Kyrgyzstan have grown at a higher rate than imports from Kazakhstan and Belarus. Nonetheless, imports from Belarus continue to account for the largest share of Russia's food supplies, particularly in commodities such as milk and meat. Indeed, Belarus has been seen as one of the distinct 'winners' in increasing its share of food imports to Russia, even though there has been some scepticism as to how much of this trade has represented re-export of EU foods. ${ }^{73}$ A closer look at the dynamics of imports from Belarus (see Fig. 2) suggests that the effect of trade disputes has been significant and USD dollar volumes of trade have still not matched the peak years of 2013-2014.

It should be noted that the value of agri-food imports from the EAEU has grown at a faster rate than imports from the rest of the world (see Fig. 3). Yet, as with external trade, this rate has slowed down significantly after 2017, which may also be attributed to the effects of Russia's import substitution policy. Furthermore, the share of internal trade remains

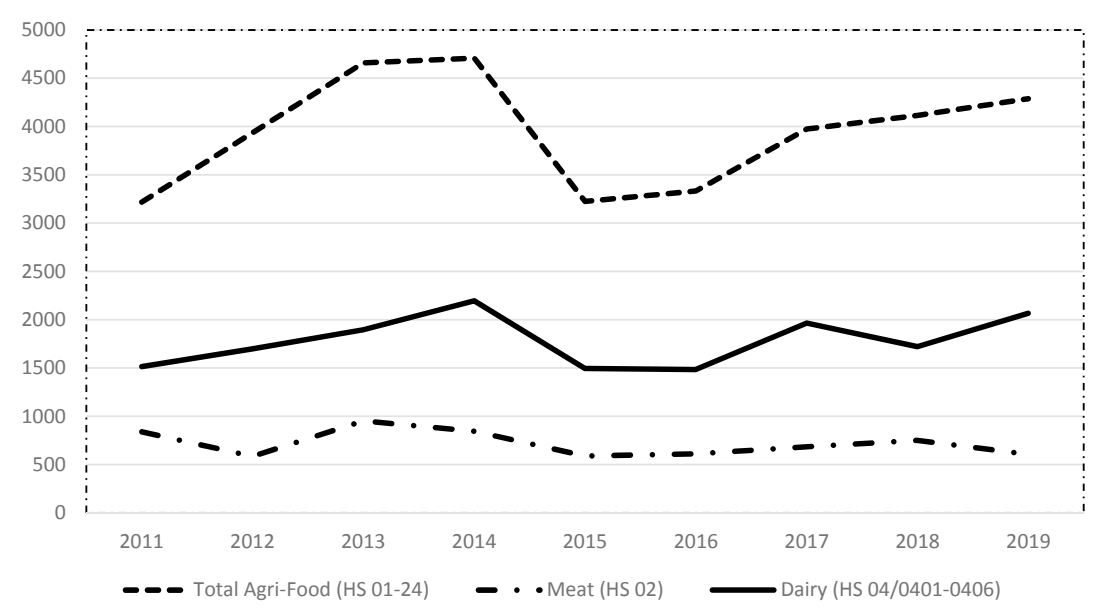

Fig. 2 Dynamics of Russia's agri-food imports from Belarus (million USD) (Source Author's calculations based on EEC's Statistics on trade in agri-food products) 


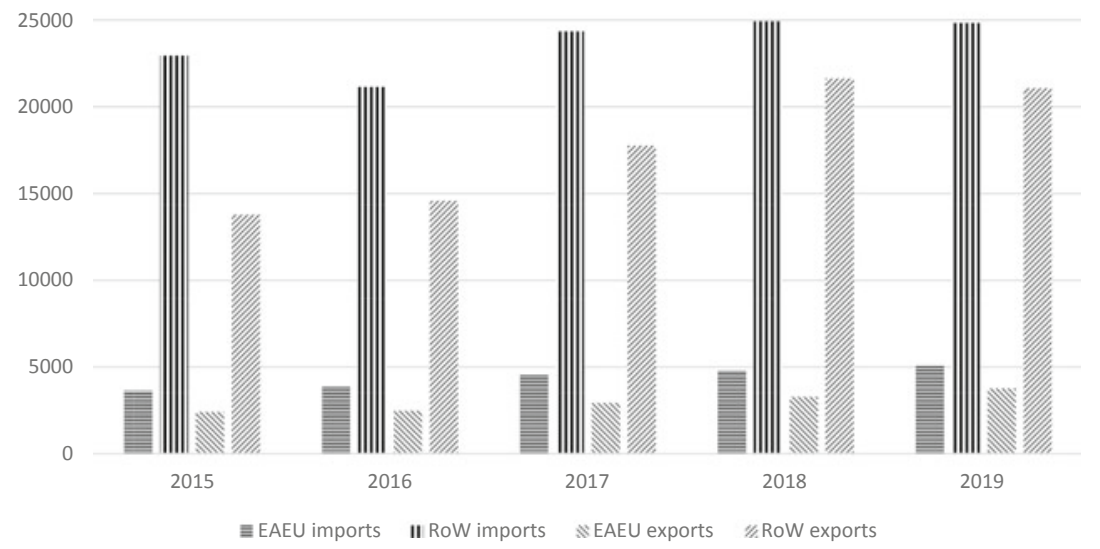

Fig. 3 Russia's agri-food imports and exports from the EAEU and rest of the world (RoW) (million USD) (Source Author's calculations based on EEC's Statistics on trade in agri-food products)

significantly lower than external agri-food trade, pointing to the prominence of other geographical regions in replacing the countries subject to the import ban.

Russia remains a net food importer from the EAEU. It has increased its exports to the EAEU albeit at a rate slower than its exports to the rest of the world. ${ }^{74}$

\section{OUTLOOK}

Over the last decade, Russia sought to increase its influence in the global food trade while promoting its geopolitical priorities. At the same time, it committed to deep economic integration within the 2010 Customs Union and the EAEU, including the creation of a common internal market and the pursuit of a common external trade policy. In this sense, the EAEU has the potential to enhance Russia's policy options in the international arena while growing regional trade. 
As the discussion in this chapter shows, however, the EAEU has had a trivial role in affecting Russia's policy choices. Given the bloc's institutional characteristics and structure, Russia's has proved able to deviate from the constraining obligations under the EAEU regime. It has been able to assert its interests regardless of the costs to its partners and the integration project as a whole. At the same time, it has allowed Moscow to use the EAEU platform to further its own priorities with limited commitment to its partners, as the example of the import substitution agenda demonstrates. Given Russia's leadership within the organisation, the EAEU has provided it with the regional clout to enter FTA with politically strategic partners. Yet, in trade terms, the potential of these agreements has been limited.

At the same time, for Russia, dealing in the context of the EAEU framework has not been problem-free. Ironically, the decentralised nature of the EAEU agri-food regime combined with the weakness of domestic institutions in the EAEU member states has meant that Moscow has struggled to enforce its import food ban. Furthermore, the weakness of the common regime has also meant that the EAEU continues to perform below its potential, particularly in growing mutual trade through the elimination of non-tariff barriers.

The problems of the EAEU have often been attributed to 'underintegration', or the insufficient extent to which member states have committed to creating a robust institutional regime for eliminating internal obstacles to trade. ${ }^{75}$ The latest 'Strategy for the Development of Eurasian Integration Until 2025' has reflected on this issue, declaring the importance of the completion of the common market and the improvement of the EAEU regulatory regime. ${ }^{76}$ Nonetheless, it is questionable if these issues can be sorted out without a radical change in the institutional setting of the Union, even if plans and programmes continue to proliferate. Indeed, as wisely observed, drawing up a roadmap to address sticking points, is 'the EAEU's favourite method for kicking things into the long grass'. ${ }^{7}$

Against this background, it can be expected that some improvements of the Union regime will take place: particularly in areas aligning with Russia's interest, such as digital tracing of origin. However, the deeper structural problems behind it, both at Union and domestic governance levels, are likely to persist without a change in the fundamental preferences and modes of operation of the EAEU member states. In this sense, 
while the EAEU will continue to add to Russia's image as a bloc leader, it is unlikely to make a major difference to the essence of its policies.

\section{Notes}

1. The founding Treaty of the EAEU was signed by Russia, Kazakhstan and Belarus on 29 May 2014. It entered into force on 1 January 2015, the formal birth of the EAEU. Armenia joined the organisation on 2 January 2015 and Kyrgyzstan on 12 August 2015.

2. Irina Gurova, Irina Platonova and Marija Maksakova, 'The Level of Trade Integration in the Eurasian Economic Union', Studies on Russian Economic Development 29, no. 4 (2018): 447-53.

3. Rilka Dragneva and Kataryna Wolczuk, 'The Eurasian Economic Union: Deals, Rules and the Exercise of Power', Chatham House Research Paper, May 2017, https://www.chathamhouse.org/sites/default/files/publicati ons/research/2017-05-02-eurasian-economic-union-dragneva-wolczuk.

pdf. Accessed 14 October 2020; Rilka Dragneva and Christopher A. Hartwell, 'The Eurasian Economic Union: Integration without Liberalisation?’ Post-Communist Economies 32, no. 7 (2020). https://doi.org/ $10.1080 / 14631377.2020 .1793586$.

4. See Stephen K Wegren, 'Russia's Foreign Food Trade: An Historical Survey', Chapter 1 , in this volume.

5. Maksim Karliuk, 'The Eurasian Economic Union: An EU-like Legal Order in the Post-Soviet Space?', HSE Working Paper BPR/LAW/2015. https://papers.ssrn.com/sol3/papers.cfm?abstract_id=2664519 2015. Accessed 20 September 2020; Rilka Dragneva, 'The Eurasian Economic Union: Balancing Sovereignty and Integration', in Post-Soviet Constitutions and Challenges of Regional Integration, eds. Roman Petrov and Peter van Elsewuge (London: Routledge, 2018), 48-70.

6. Karliuk, The Eurasian Economic Union: An EU-like Legal Order in the Post-Soviet Space?'.

7. Alexander Knobel, Andrey Lipin, Andrey Malokostov, David Tarr, and Natalia Turdyeva, 'Deeper Integration in the Eurasian Economic Union: What Are the Benefits of Successful Implementation or Wider Liberalisation?' Eurasian Geography and Economics 60, no. 2 (2019): 177-210.

8. Dragneva, 'The Eurasian Economic Union: Balancing Sovereignty and Integration'.

9. David Sedik, Carl Ulbricht, and Nuritdin Dzhamankulov, The Architecture of Food Safety Control Across Eurasia (Balti, Moldova: Lambert Academic Publishing, 2017), 46.

10. Ricardo Giucci, 'The Eurasian Economic Union-An Analysis from a Trade Policy Perspective', Presentation at the German Embassy, Moscow, 
29 May 2018. https://berlin-economics.com/wp-content/uploads/ 2018-05-29_Presentation-EAEU_Moscow.pdf. Accessed 23 September 2020.

11. Dragneva and Wolczuk, 'The Eurasian Economic Union: Deals, Rules and the Exercise of Power'.

12. Evgeny Vinokurov, 'Eurasian Economic Union: Current State and Preliminary Results', Russian Journal of Economics, no. 3 (2017): 54-70; Knobel et al., 'Deeper Integration in the Eurasian Economic Union'.

13. Alexander Melikishvilli, 'Russia's Economic Pressure on Belarus Escalates to Trade War', Jamestown Foundation Commentaries, 10 June. https://jamestown.org/russias-economic-pressure-on-belarusescalates-to-trade-war. Accessed 15 September 2020.

14. Sedik, Ulbricht, and Dzhamankulov, The Architecture of Food Safety Control, 32.

15. Irina Kireeva and Robert Black, 'Sanitary and Phytosanitary Legislation in the Russian Federation: A General Overview in Light of the WTO SPS Agreement and EU Principles of Food Safety', Review of Central and East European Law 35 (2010): 225-55.

16. Robert Black and Irina Kireeva, 'Sanitary and Phytosanitary Issues for the Customs Union of Russian Federation, Belarus and Kazakhstan in Relation to Trade with Other CIS Countries and the EU', Journal of World Trade 49, no. 5 (2015): 805-36.

17. Nuritdin Dzhamankulov, 'The Harmonization of Eurasian Economic Union Sanitary and Phytosanitary Measures and Technical Regulation for Agricultural Goods with the Provisions of the WTO for the International Trade Development', FAO Regional Office for Europe and Central Asia Policy Studies on Rural Transition No. 2015-5. http://www.fao.org/3/ a-bs205e.pdf. Accessed 14 September 2020.

18. Article 53.2 paragraph 3 of the EAEU Treaty. Available at https:// docs.eaeunion.org/docs/ru-ru/0023611/itia_05062014. Accessed 14 October 2020 .

19. Article 56. 2 of the EAEU Treaty. Available at https://docs.eaeunion. org/docs/ru-ru/0023611/itia_05062014. Accessed 14 October 2020.

20. Articles 51-52 provide the general framework for technical standards, whereas Articles 56-59 and Annex 12 are specifically dedicated to SPS measures.

21. CU Commission Decision No 299 of 28 May 2010. Available at http:// www.tsouz.ru/kts/kts17/pages/r_299.aspx. Accessed 14 October 2020. As technical regulations get adopted, the respective products are deleted from the general list under Decision No. 299.

22. For an up-to-date list, see http://www.eurasiancommission.org/ru/ act/texnreg/deptexreg/tr/Pages/TRVsily.aspx. Accessed 17 September 2020 . 
23. CU Commission Decision No. 317 of 18 June 2010. Available at http:// www.tsouz.ru/KTS/KTS17/Pages/R_317.aspx. Accessed 14 October 2020.

24. Evraziiskaia ekonomicheskaia komissiia (hereafter EEK), 'EEK predlagaet izmenit' poryadok razrabotki soyuznykh tehreglamentov i uzhestochit' kontrol' za soblyudeniem ustanovlennykh srokov', 11 October 2019. http://www.eurasiancommission.org/ru/nae/news/Pages/11-10-20191.aspx. Accessed 19 September 2020.

25. Il'a Zakharkin, 'Chto ozhidaet rynok vina v EAES?' Ritm Evrazii, 30 July 2020. http://www.ritmeurasia.org/news--2020-07-30--chto-ozh idaet-rynok-vina-v-eaes-50195. Accessed 17 September 2020.

26. Article 57.4 of the EAEU Treaty.

27. Such an agreement has been in the making since 2015, with a draft approved by the EEC Council in February 2018 and disseminated to member states for discussion, yet progress has been slow.

28. The Collegium of the EEC adopted two non-binding acts to promote coordination in this field: on how member states' bodies should cooperate with each other when exercising domestic control for compliance with technical regulations (Recommendation No 9 of 19 June 2018) and how they should cooperate with the Commission to prevent the circulation of non-compliant goods (Recommendation no. 22 from 23 July 2019).

29. EEK, 'V EAES dolzhna provodit'sia edinaia politika po primeneniiu sanitarnykh i fitosanitarnykh mer', 25 October 2018. http://www.eurasianc ommission.org/ru/nae/news/Pages/25-10-2018-1v.aspx. Accessed 19 September 2020.

30. For a comprehensive comparison between the EAEU and the EU in the area of food safety, see discussion of this aspect see, Sedik, Ulbricht, and Dzhamankulov, The Architecture of Food Safety Control.

31. Paragraph 6 of Annex 12 of the EAEU Treaty. Available at https:// docs.eaeunion.org/docs/ru-ru/0023611/itia_05062014. Accessed 14 October 2020.

32. Council of the Eurasian Economic Commission. Decision no. 149 from 16 May 2016. Available at http://www.tsouz.ru/KTS/KTS17/Pages/ R_317.aspx. Accessed 14 October 2020.

33. For a detailed discussion of this point, see Sedik, Ulbricht, and Dzhamankulov, The Architecture of Food Safety Control.

34. EEK, 'Doklad o realizatzii osnovnykh napravlenii integratzii v ramkakh Evraziiskogo ekonomicheskogo soiuza v 2018', n.d. http://www.eurasi ancommission.org/ru/act/integr_i_makroec/dep_razv_integr/Docume nts $/ \% \mathrm{~d} 0 \% 94 \% \mathrm{~d} 0 \% \mathrm{be} \% \mathrm{~d} 0 \% \mathrm{ba} \% \mathrm{~d} 0 \% \mathrm{bb} \% \mathrm{~d} 0 \% \mathrm{~b} 0 \% \mathrm{~d} 0 \% \mathrm{~b} 4 \% 20 \% \mathrm{~d} 0 \% \mathrm{~b} 8 \% \mathrm{~d} 0 \%$ bd $\% \mathrm{~d} 1 \% 82 \% \mathrm{~d} 0 \% \mathrm{~b} 5 \% \mathrm{~d} 0 \% \mathrm{~b} 3 \% \mathrm{dl} \% 80 \% \mathrm{~d} 0 \% \mathrm{~b} 0 \% \mathrm{dl} \% 86 \% \mathrm{~d} 0 \% \mathrm{~b} 8 \% \mathrm{dl} \% 8 \mathrm{f}$.pdf. Accessed 17 September 2020. 
35. Author's interview with the EEC's Minister of Integration, Tatyana Valovaya, July 2014.

36. EEK, 'Viktor Nazarenko: Sistema ozenki sootvetstviia i gosudarstvennogo nadzora dolzhny byt' vystroeny takim obrazom, chto na obshcgii rynok postupala tol'ko kachestvennaia i bezopasnaia produkziia', 27 February 2020. http://www.eurasiancommission.org/ru/nae/news/ Pages/27-02-2020-1.aspx. Accessed 19 September 2020.

37. Under Article 58.6 of the EAEU Treaty.

38. Article 29.3 of the EAEU Treaty.

39. For example, see Kirill Sokov, 'Molochno-tzenovoi disbalans mezhdu Moskvoi i Minskom', 18 March 2018. https://www.ritmeurasia.org/ news--2018-03-08--molochno-cenovoj-disbalans-mezhdu-moskvoj-i-min skom-35313. Accessed 22 September 2020.

40. Government Resolution no. 778 of 7 August 2014 banned imports of certain agricultural products from Australia, Canada, the EU, Norway and the USA. http://government.ru/docs/14195. Accessed 14 October 2020; Government Resolution no. 842 of 13 August 2015 extended the ban to Albania, Iceland, Lichtenstein and Montenegro. From 1 January 2016, the ban was extended to Ukraine. http://government.ru/docs/ 19265. Accessed 14 October 2020.

41. Alexander Knobel', 'Nevozmozhnaia troitsa; kak rossiiskie sanktsii razrushaiut Tamozhennyi soiuz', 2 December 2014. http://www.forbes. $\mathrm{ru} /$ mneniyacolumn/gosplan/274627-nevozmozhnaya-troitsa-kak-rossii skie-sanktsii-razrushayuttamozhennyi. Accessed 26 September 2020.

42. Volha Charnysh, 'Belarus Hopes to Cash in on Russian Sanctions', 19 August 2014. https://belarusdigest.com/story/belarus-hopes-to-cash-inon-russian-sanctions/. Accessed 22 September 2020.

43. For a discussion of this issue, see Jurii Kofner, 'Did the EaEU Create a Common Market for Goods, Services, Capital and Labour Within the Union?', 30 October 2019. https://12v.blogactiv.eu/2019/10/30/ did-the-eurasian-economic-union-create-a-common-domestic-market-forgoods-services-capital-and-labor/. Accessed September 9, 2020.

44. Viktor Rogozhin, 'Moloko i myaso is Belarussii ne na stole potrebitelei, v leksikone politikov', 1 April 2018. https://www.ritmeurasia.org/ news--2018-04-01--moloko-i-mjaso-iz-belorussii-ne-na-stole-potrebite lej-a-v-leksikone-politikov-35701. Accessed 2 September 2020. See also Rosselkhoznadzor's report from the inspections carried out on Belarus's enterprises in June 2018. https://fsvps.gov.ru/fsvps-docs/ru/import Export/belarus/files/inspection_2018061215_pre.pdf. Accessed 20 September 2020.

45. EEK, 'Sergey Sidorskii: "Produktsiia zhivotnogo proizhozhdeniia Belarusi otvechaet vsem trebovaniiam veterinarno-sanitarnogo kontrolia EAES"”, 
11 January 2017. http://www.eurasiancommission.org/ru/nae/news/ Pages/11-01-2017.aspx. Accessed 22 September 2020.

46. EEC Collegium Decision no. 181 of 12 November 2018, https://docs. eaeunion.org/docs/ru-ru/01424926/clcd_16112018, and Decision no. 11 of 22 January 2019. https://docs.eaeunion.org/docs/ru-ru/014 23704/clcd_25012019_11, both accessed 14 October 2020, in relation to restrictions on milk.

47. Il 'ya Zakharkin, 'Kak prekratit' belorussko-rossiiskie 'igry' v ogranicheniia?', 13 May 2019. https://www.ritmeurasia.org/news-2019-05-13--kak-prekratit-belorussko-rossijskie-igry-v-ogranichenija42604. Accessed 22 September 2020.

48. Kofner, 'Did the EaEU Create a Common Market?'

49. For an analysis of food security and different dimensions that relate to it in Russia see Stephen K. Wegren, Alexander Nikulin, and Irina Trotsuk,Food Policy and Food Security: Putting Food on the Russian Table (Lanham, MD and London, UK: Lexington Books, 2018).

50. EEK, 'Monitoring prodovolstvennoi bezopasnosti EAES: 2014', Moscow, 2015. http://www.eurasiancommission.org/ru/act/prom_i_agroprom/ dep_agroprom/monitoring/Documents/\%D0\%9C\%D0\%BE\%D0\%BD $\%$ D0\%B8\%Dl\%82\%D0\%BE\%Dl\%80\%D0\%B8\%D0\%BD\%D0\%B3\%20\%D0\% BF\%Dl\%80\%D0\%BE\%D0\%B4\%D0\%BE\%D0\%B2\%D0\%BE\%D0\%BB\%Dl\% $8 \mathrm{C} \% \mathrm{Dl} \% 81 \% \mathrm{Dl} \% 82 \% \mathrm{D} 0 \% \mathrm{~B} 2 \% \mathrm{D} 0 \% \mathrm{~B} 5 \% \mathrm{D} 0 \% \mathrm{BD} \% \mathrm{D} 0 \% \mathrm{BD} \% \mathrm{D} 0 \% \mathrm{BE} \% \mathrm{D} 0 \%$ B9\%20\%D0\%Bl\%D0\%B5\%D0\%B7\%D0\%BE\%D0\%BF\%D0\%B0\%Dl\%81\% D0\%BD\%D0\%BE\%Dl\%81\%Dl\%82\%D0\%B8\%20\%D0\%Al\%D0\%BE\%Dl\% 8E\%D0\%B7\%D0\%B0\%202014.pdf. Accessed 14 October 2020.

51. Article 94.2 of the EAEU Treaty.

52. Article 95.2 of the EAEU Treaty.

53. Decision of the Council of the EEC no. 66 of 12 February 2016. https://docs.eaeunion.org/docs/ru-ru/01414425/cncd_10102016_66. Accessed 14 October 2020.

54. EEK, 'Monitoring prodovolstvennoi bezopasnosti'.

55. EEK, 'V EAES sistemno podoidut $\mathrm{k}$ razvitiiu APK', 17 July 2020. http://www.eurasiancommission.org/ru/nae/news/Pages/17.07. 2020-5 aspx. Accessed 24 September 2020.

56. Jurii Kofner, 'Did the Other EAEU Member States Profit from Eurasian Integration and Russia's Countersanction Policy?', 3 July 2020. http:// greater-europe.org/archives/8091. Accessed 23 September 2020.

57. EEK, 'Obzor kliuchevykh polozhenii soglasheniia o svobodnoi torgovle mezhdu Evraziiskim ekonomicheskim soiuzom i sotzialisticheskoi Respubliki Vietnam', Moscow, 2015. http://eec.eaeunion.org/ru/act/trade/ dotp/sogl_torg/Documents/\%d0\%9e\%d0\%bl\%d0\%b7\%d0\%be\%dl \%80\% $20 \% \mathrm{~d} 0 \% \mathrm{al} \% \mathrm{~d} 0 \% \mathrm{be} \% \mathrm{~d} 0 \% \mathrm{~b} 3 \% \mathrm{~d} 0 \% \mathrm{bb} \% \mathrm{~d} 0 \% \mathrm{~b} 0 \% \mathrm{dl} \% 88 \% \mathrm{~d} 0 \% \mathrm{~b} 5 \% \mathrm{~d} 0 \% \mathrm{bd} \% \mathrm{~d} 0 \%$ b8\%dl\%8f\%20\%d0\%be\%20\%dl\%81\%d0\%b2\%d0\%be\%d0\%bl\%d0\%be\%d0\% 
b4\%d0\%bd\%d0\%be\%d0\%b9\%20\%dl \%82\%d0\%be\%dl \%80\%d0\%b3\%d0\%be \% d0\%b2\%d0\%bb\%d0\%b5\%20\%d0\%bc\%d0\%b5\%d0\%b6\%d0\%b4\%dl\%83\%20\% dl $\% 81 \%$ dl $\% 82 \%$ dl $\% 80 \% d 0 \%$ b0\%d0\%bd\%d0\%b0\%d0\%bc\%d0\%b8\%20\%d0\% 95\%d0\%90\%d0\%ad\%d0\%al\%20\%d0\%b8\%20\%d0\%92\%dl\%8c\%d0\%b5\%dl\% $82 \% \mathrm{~d} 0 \%$ bd $\% \mathrm{~d} 0 \%$ b0\%d0\%bc\%d0\%be\%d0\%bc.pdf. Accessed 14 October 2020.

58. For example, rice is subject to 10 thousand tonn quota, which is less than 5 percent of total imports from third countries, and applies to long-grain rice, which is not grown in the EAEU.

59. EEK, 'Annotatzia $k$ rezultatam nauchno-issledovatel'skoi raboty na temu “Opredelenie perspektivnykh partnerov gosudarstv-chlenov Tamozhennogo Soiuza po zakliucheniiu soglashenii o svobodnoi torgovle"', 2013. http://www.eurasiancommission.org/ru/NIR/Lists/List/ Attachments/35/18_12_2013_annot.pdf. Accessed 21 September 2020.

60. Sam Bhutia, 'As the Eurasian Union Looks East, Its Deals Do Not Benefit All Members Equally', 19 November 2019. https://eurasianet. org/as-the-eurasian-union-looks-east-its-deals-do-not-benefit-all-mem bers-equally. Accessed 20 September 2020.

61. Author's calculation from data in the EEC's Statistics. http://www.eurasi ancommission.org/ru/act/integr_i_makroec/dep_stat/tradestat/tables/ Pages/default.aspx. Accessed 28 September 2020.

62. This section uses 2018 data on third countries' share in EAEU and its members' trade, presented in Dragneva and Hartwell, 'The Eurasian Economic Union: Integration Without Liberalisation', 15-16.

63. TASS, 'Iran i EAES mogut sozdat' postoiannuiu zonu svododnoi torgovli do kontsa goda', 2 November 2020. https://www.dairynews.ru/news/ iran-i-eaes-mogut-sozdat-postoyannuyu-zonu-svobodn.html. Accessed 2 November 2020.

64. Rilka Dragneva, 'The Eurasian Economic Union: Putin's Geopolitical Project', FPRI Research Paper, 15 October 2018. https://www.fpri. org/wp-content/uploads/2018/10/rpe-6-dragneva-final2.pdf. Accessed 20 September 2020.

65. TASS, 'Iran i EAES mogut sozdat' postoiannuiu zonu svododnoi torgovli do kontsa goda'.

66. EEK, 'Annotatzia k rezultatam nauchno-issledovatel'skoi raboty na temu'. 67. Ibid.

68. Dragneva, 'The Eurasian Economic Union: Putin's Geopolitical Project'.

69. Dragneva and Hartwell, 'The Eurasian Economic Union: Integration Without Liberalisation'.

70. EEK, Doklad 'O rezul'tatakh analiza dinamiki vzaimnoi torgovli gosudarst-chlenovTamozhennogo soiuza i Edinogo ekonomicheskogo prostranstvo v 2010-2014 godakh', 2015. http://www.eurasiancommiss 
ion.org/ru/act/integr_i_makroec/dep_stat/tradestat/analytics/Docume nts/report/Report_2010-2014.PDF. Accessed 24 September 2020.

71. FAO, 'Agricultural Trade Policies in the Post-Soviet countries 2014/2015: A Summary', 2016. http://www.fao.org/3/a-i6l60e.pdf. Accessed 24 September 2020.

72. EEK, Doklad 'O rezul'tatakh analiza dinamiki vzaimnoi torgovli'.

73. Kofner, 'Did the Other EAEU Member States Profit from Eurasian Integration and Russia's Countersanction Policy?'

74. FAO, 'Review of Agricultural Trade Policies in the Post-Soviet Countries 2017-2018', 2020. http://www.fao.org/3/CA0879EN/ca0879en. pdf. Accessed 22 September 2020.

75. E.g. see the statements of the then President of the EEC Collegium: "Tigran Sarkisian na PMEF-2019," 7 June 2019, https://xn----8sb eibfw3aojl2n.xn--plai/eaes/tigran-sarkisyan-v-vosplamenyayushchemsyamire-\%D0\%B5ek-ne-hvataet-polnomochij. Accessed 22 September 2020.

76. EEK, 'Sovet EEK soglasoval eshche 28 punktov proekta Strategii-25', 1 October 2020. http://www.eurasiancommission.org/ru/nae/news/ Pages/01-10-2020-3.aspx. Accessed 1 October 2020.

77. Eurasianet, 'Here's Looking at EAEU \&\#xF023;4: Belarus Backs Itself into Trade Corner', 3 September 2020. https://eurasianet.org/hereslooking-at-eaeu-4-belarus-backs-itself-into-trade-corner. Accessed 24 September 2020.

\section{SELECTED BibLIOGRAPHY}

Bhutia, Sam. 'As the Eurasian Union Looks East, Its Deals Do Not Benefit All Members Equally'. Eurasianet.org, 19 November 2019. Available at https://eurasianet.org/as-the-eurasian-union-looks-east-its-deals-donot-benefit-all-members-equally.

Black, Robert and Irina Kireeva. 'Sanitary and Phytosanitary Issues for the Customs Union of Russian Federation, Belarus and Kazakhstan in Relation to Trade with Other CIS Countries and the EU'. Journal of World Trade 49, no. 5 (2015): 805-36.

Dragneva, Rilka and Christopher A. Hartwell. 'The Eurasian Economic Union: Integration without Liberalisation?' Post-Communist Economies 32, no. 7 (2020). Available at https://doi.org/10.1080/14631377.2020.1793586.

Dragneva, Rilka and Kataryna Wolczuk. 'The Eurasian Economic Union: Deals, Rules and the Exercise of Power'. Chatham House Research Paper, May 2017. Available at https://www.chathamhouse.org/sites/default/files/pub lications/research/2017-05-02-eurasian-economic-union-dragneva-wolczuk. pdf. 
Dragneva, Rilka. 'The Eurasian Economic Union: Balancing Sovereignty and Integration', in Post-Soviet Constitutions and Challenges of Regional Integration, eds. Roman Petrov and Peter van Elsewuge. London: Routledge, 2018, 48-70.

Dragneva, Rilka. 'The Eurasian Economic Union: Putin's Geopolitical Project'. FPRI Research Paper, 15 October 2018. Available at https://www.fpri.org/ wp-content/uploads/2018/10/rpe-6-dragneva-final2.pdf.

Dzhamankulov, Nuritdin. 'The Harmonization of Eurasian Economic Union Sanitary and Phytosanitary Measures and Technical Regulation for Agricultural Goods with the Provisions of the WTO for the International Trade Development'. FAO Regional Office for Europe and Central Asia Policy Studies on Rural Transition No. 2015-5. Available at http://www.fao.org/ $3 / a-b s 205 e . p d f$.

FAO. 'Agricultural Trade policies in the Post-Soviet countries 2014/2015: A Summary', 2016. Available at http://www.fao.org/3/a-i6160e.pdf.

FAO. 'Review of Agricultural Trade Policies in the Post-Soviet Countries 20172018: A Summary', 2020. Available at http://www.fao.org/3/CA0879EN/ ca0879en.pdf.

Giucci, Ricardo and Anne Mdinaradze. 'The Eurasian Economic Union-An Analysis from a Trade Policy Perspective', Berlin Economics, 11 April 2017. Available at https://wiiw.ac.at/files/events/giucci-eaeu-11-april-2017-en-n341.pdf.

Gurova, Irina, Platonova, Irina and Marija Maksakova. 'The Level of Trade Integration in the Eurasian Economic Union'. Studies on Russian Economic Development 29, no. 4 (2018): 447-53.

Karliuk, Maksim. 'The Eurasian Economic Union: An EU-like Legal Order in the Post-Soviet Space?', HSE Working Paper BPR/LAW/2015. Available at https://papers.ssrn.com/sol3/papers.cfm?abstract_id=2664519 2015.

Kireeva, Irina and Robert Black. 'Sanitary and Phytosanitary Legislation in the Russian Federation: A General Overview in Light of the WTO SPS Agreement and EU Principles of Food Safety'. Review of Central and East European Law 35 (2010): 225-55.

Knobel, Alexander, Lipin, Andrey, Malokostov, Andrey, Tarr, David and Natalia Turdyeva. 'Deeper Integration in the Eurasian Economic Union: What Are the Benefits of Successful Implementation or Wider Liberalisation?' Eurasian Geography and Economics 60, no. 2 (2019): 177-210.

Kofner, Jurii. 'Did the EaEU Create a Common Market for Goods, Services, Capital and Labour Within the Union?', 30 October 2019. Available at https://12v.blogactiv.eu/2019/10/30/did-the-eurasian-economic-unioncreate-a-common-domestic-market-for-goods-services-capital-and-labor/. 
Kofner, Jurii. 'Did the Other EAEU Member States Profit from Eurasian Integration and Russia's Countersanction Policy?', Analytical Media Eurasian Studies, 3 July 2020. Available at http://greater-europe.org/archives/8091.

Sedik, David, Ulbricht, Carl and Nuritdin Dzhamankulov. The Architecture of Food Safety Control Across Eurasia. Balti, Moldova: Lambert Academic Publishing, 2017.

Vinokurov, Evgeny. 'Eurasian Economic Union: Current State and Preliminary Results'. Russian Journal of Economics, no. 3 (2017): 54-70.

Wegren, Stephen K., Nikulin, Alexander and Irina Trotsuk. Food Policy and Food Security: Putting Food on the Russian Table. Lanham, MD and London, UK: Lexington Books, 2018.

Open Access This chapter is licensed under the terms of the Creative Commons Attribution 4.0 International License (http://creativecommons.org/licenses/ by $/ 4.0 /)$, which permits use, sharing, adaptation, distribution and reproduction in any medium or format, as long as you give appropriate credit to the original author(s) and the source, provide a link to the Creative Commons license and indicate if changes were made.

The images or other third party material in this chapter are included in the chapter's Creative Commons license, unless indicated otherwise in a credit line to the material. If material is not included in the chapter's Creative Commons license and your intended use is not permitted by statutory regulation or exceeds the permitted use, you will need to obtain permission directly from the copyright holder.

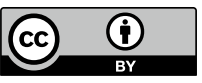

